\title{
Effect of Self Repairing Mechanism in Concrete using Biometric Materials
}

\author{
Kesava Raja. $\mathrm{C}^{1}$ \\ Assistant Professor, \\ Civil Engineering Department, \\ Saranathan College of Engineering, Panjapur, \\ Tiruchirapalli-12, India,
}

\author{
Yuvatharani. $\mathrm{P}^{2}$ \\ U. G. Student (B.E), \\ Civil Engineering Department, \\ Saranathan College of Engineering, Panjapur, \\ Tiruchirapalli-12, India, \\ Kalpana. $A^{3}$ \\ U. G. Student (B.E), \\ Civil Engineering Department, \\ Saranathan College of Engineering, Panjapur, \\ Tiruchirapalli-12, India,
}

\author{
Abinaya. $\mathrm{R}^{4}$ \\ U. G. Student (B.E), \\ Civil Engineering Department, \\ Saranathan College of Engineering, Panjapur, \\ Tiruchirapalli-12, India, \\ Padmavathi. $\mathrm{V}^{5}$ \\ U. G. Student (B.E), \\ Civil Engineering Department, \\ Saranathan College of Engineering, Panjapur, \\ Tiruchirapalli-12, India,
}

\begin{abstract}
Cracks are easily formed in Concrete. Due to the high tensile stresses the cracks may be formed on the concrete surface. As wider the cracks endangers the strength and durability of concrete structures, So that the cost of maintenance to repair may be required. In order to enhance strength and durability cracks should be filled with bonding and inert materials. By repair and maintenance of concrete structure a high economic condition occurs. In this study the BIOMATIC MATERIALS are used to induce $\mathrm{CaCO}_{3}$. Biomatic Materials used was Bacillus subtilis bacteria. Biochemically induced calcite precipitate will help in the healing the premature cracks formed in the concrete structures. By providing self-healing agents $50 \%$ of maintenance cost is reduced. This study mainly focus on to enhance the ability of self-repairing mechanism of the concrete by the help of formation of calcite precipitation. It is also an attempt to reduce the burden of frequent maintenance and manual repair works thus resulting in increase of lifetime of the concrete structures. Since the crack formation is major threat for the concrete structures this will study will help to overcome those catastrophic situations. Hence by using this innovative technique of cracking healing in the concrete structures the strength and durability will be increased compared to the conventional concrete.
\end{abstract}

Key Words: Bio-matic Materials, Bacillus subtilis, Calcium Carbonate $\left(\mathrm{CaCo}_{3}\right)$, Self-repairing mechanism.

\section{INTRODUCTION}

Concrete is a material which is the most widely used in construction of the buildings in the world.Natural processes such as weathering, faults, land subsidence, earthquakes, and human activities are the main reasons for creating cracks in concrete structures. The common problem found in buildings is Crack. Crack may be due to many reasons. Some reasons are Expansion and shrinkage of concrete due to temperature change in the environment, Settlement of structure, Due to heavy load applied, Due to loss of water from concrete surface when shrinkage occurs, Insufficient vibration at the time of laying the concrete, Improper cover, High water cement ratio to make the concrete workable, Due to corrosion of reinforcement steel, Many mixtures with rapid setting. Cracks makes the Concrete to look unpleasant becauseit forms an open pathway to the reinforcement and can lead to durability problems like corrosion of the steel bars. These cracks should be repaired because they can reduce the service lifetime of the structure.In case of historical monuments, cracks makes the structure to appear spoilt.Remediation of existing cracks has been subject of research for many years. The products such as structural epoxy, resins, epoxy mortar, and other synthetic mixtures are used as filling material for cracks in concrete but they are not environmentally friendly not even safe for human health.Here are some four possible mechanisms given for self-healing of concrete which are as follows

- Formation of material like calcite

- Blocking of the path by sedimentation of Particles

- Continued hydration of cement particles

- Swelling of the surrounding cement matrix.

\subsection{SELF-HEALING CONCRETE}

Self-healing concrete consists of a conventional mix with bacteria incorporated into the concrete and calcium lactate to provide food to support those bacteria when they become active. The bacteria which is feeding on the provided food source heals the damage done and also reduces the amount of damage sustained by the concrete structure in place.Special type of bacteria's known as 
Bacillus subtilis from Bacillus family are used along with calcium nutrient known as Calcium Lactate. While preparation of this concrete, these products are added in the wet concrete when the mixing is done. This bacteria's lifetime is about for around 200 years. When the cracks appear in the concrete, the water seeps in the cracks. The spores of the bacteria starts to grow (germinate) and starts feeding on the calcium lactate consuming oxygen. Insoluble limestone is converted from the soluble calcium lactate. The insoluble limestone starts to harden. Thus filling the crack, automatically without any external requirements. When concrete structures are made with bacterial concrete, when the crack occurs in the structure the bacteria germinate and eat down the calcium lactate which is formed by the broken clay pellets of the structure and produce limestone, which hardens and thus sealing the cracks.

\subsection{MATERIAL TESTING}

Materials used for the self- healing concrete is based upon the efficient usage of their properties. The material is tested for cement, coarse aggregate and fine aggregate. For cement Consistency and Initial setting time is tested. For coarse aggregate Specific gravity, Crushing strength, Impact value is tested. For fine aggregate Water absorption, Specific gravity is tested of the material properties as per Indian standard code provisions.

\subsection{SAMPLE COLLECTION}

To attain the goals, materials were collected from various sources. Material collection is the basic and important step in any project. Yet the material used in this study should not cause any damage to the environment. For the selfhealing concrete the specimens are prepared in various process. The samples are micro-organisms, chemicals for healing agent, materials used for conventional concrete.

\subsection{CASTING AND CURING}

The cube and the cylinder specimen are casted for conventional and self-healing concrete. The mix proportion is $\mathrm{M}_{20}$ as per IS 10262-2009. After 24 hours of casting the specimens are demoulded, these specimens are immersed into water for curing process for 28 days. After the curing the specimens are subjected to testing.

\subsection{TESTING TECHNIQUE}

After the curing process the specimens were tested. The specimens are tested for Compressive strength test, Flexural strength test, Modulus of elasticity test, Surface crack healing test, Scanning Electron Microscope test for internal cracks.

\section{A) COMPRESSIVE STRENGTH TEST}

The results for the compressive test of cube specimen is given in tabulation

TABLE - 1 Compressive Strength of Concrete

\begin{tabular}{|c|c|}
\hline Quantity of bacteria (ml) & $\begin{array}{l}\text { Compressive strength for } 28^{\text {th }} \text { day in } \\
\mathrm{N} / \mathrm{mm}^{2}\end{array}$ \\
\hline 0 & 21 \\
\hline 30 & 34 \\
\hline 35 & 36 \\
\hline 40 & 22 \\
\hline
\end{tabular}

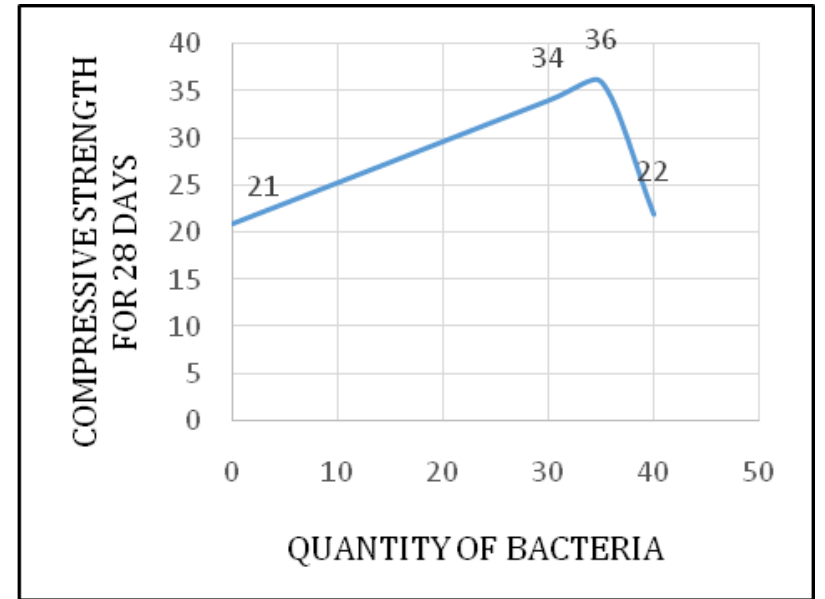

\section{Chart - 1. GRAPHICAL REPRESENTATION OF} COMPRESSIVE STRENGTH

X AXIS - Quantity of bacteria IN ml

Y AXIS - Compressive strength for 28 days in N/mm²

B) FLEXURAL STRENGTH TEST

The results for the Flexural test of beam specimen is given in tabulation

TABLE - 2 Flexural Strength of Concrete

\begin{tabular}{|c|c|}
\hline Quantity of bacteria (ml) & $\begin{array}{l}\text { Flexural } \\
\mathrm{N} / \mathrm{mm}^{2}\end{array}$ \\
\hline 0 & \multicolumn{2}{|c|}{ strength for $28^{\text {th }}$ day in } \\
\hline 30 & 24.50 \\
\hline 35 & 25.07 \\
\hline 40 & 18.05 \\
\hline
\end{tabular}

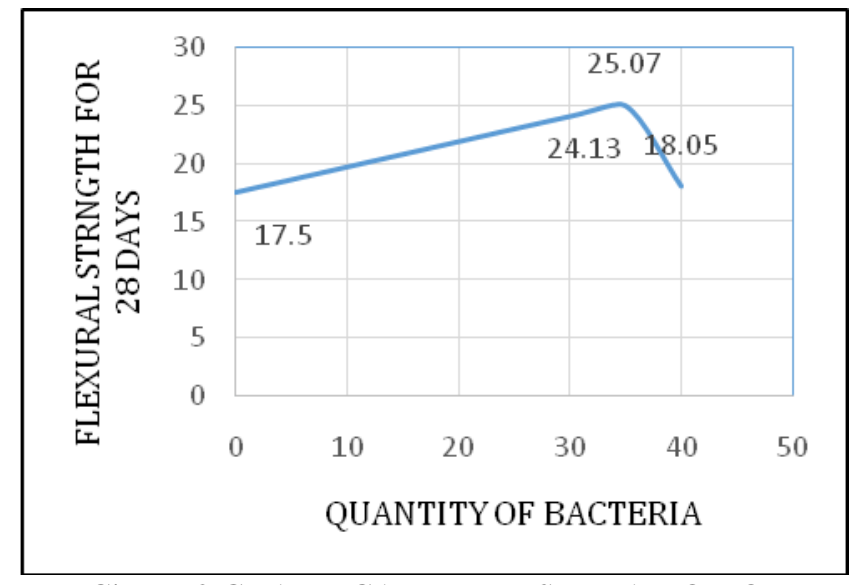

Chart - 2 GRAPHICAL REPRESENTATION OF FLEXURAL STRENGTH

X AXIS - Quantity of bacteria IN ml Y AXIS - Flexural strength for 28 days in N/mm² C) MODULUS OF ELASTICITY

The results for the Flexural test of beam specimen is given in tabulation 
TABLE - 2 Modulus of Elasticity of Concrete

\begin{tabular}{|c|c|}
\hline Quantity of bacteria $(\mathrm{ml})$ & $\begin{array}{l}\text { Modulus of Elasticity for } 28^{\text {th }} \text { day } \\
\text { in N/mm }\end{array}$ \\
\hline 0 & $2.436^{*} 10^{6}$ \\
\hline 30 & $3.100^{*} 10^{6}$ \\
\hline 35 & $3.190 * 10^{6}$ \\
\hline 40 & $2.494 * 10^{6}$ \\
\hline
\end{tabular}

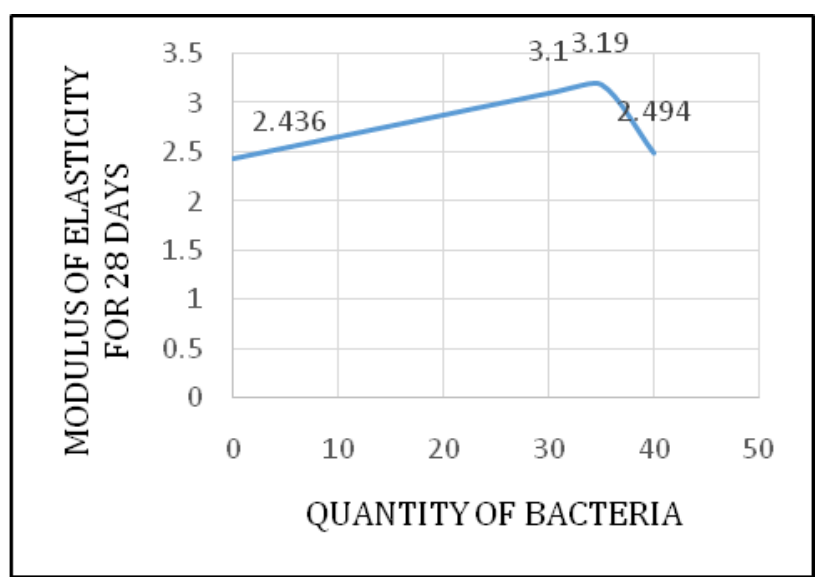

Chart - 3 GRAPHICAL REPRESENTATION OF MODULUS OF ELASTICITY

X AXIS - Quantity of bacteria IN ml

Y AXIS - Modulus of elasticity for 28 days in $10^{\wedge} 6 \mathrm{~N} / \mathrm{mm}^{2}$ D) SURFACE CRACK HEALING

The surface crack healed for $35 \mathrm{ml}$ of bacteria was shown in figure

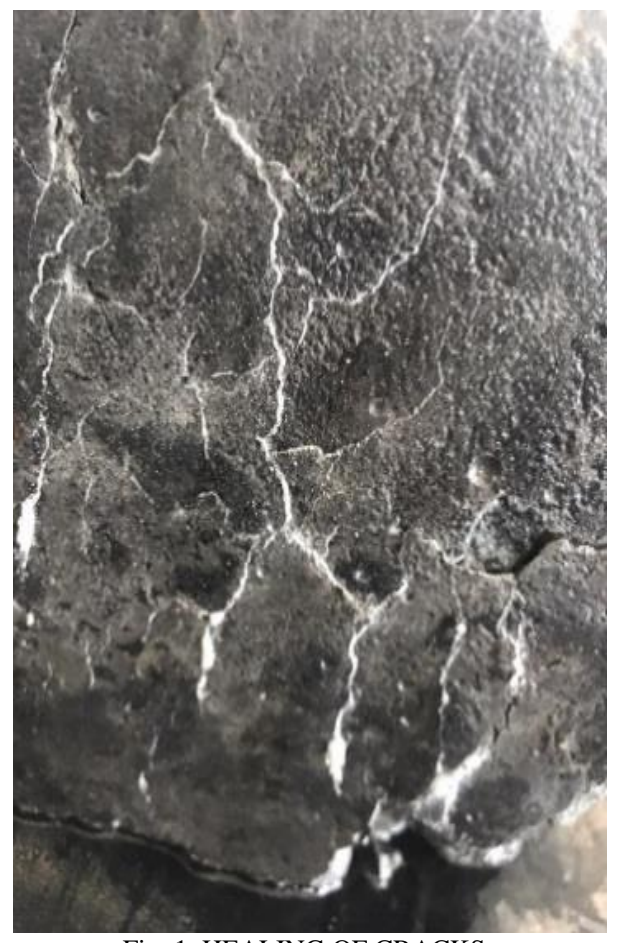

Fig. 1. HEALING OF CRACKS

\section{CONCLUSIONS}

$\checkmark \quad$ The Self-healing concrete using Bacillus subtilis of $35 \mathrm{ml}$ shows greater compressive strength and there is a decline in compressive strength of 40 $\mathrm{ml}$.

$\checkmark \quad$ The crack healing ratio decreases for increase in curing period.

$\checkmark \quad$ The characteristics of internal cracks is studied by using Scanning Electron Microscope (SEM) analysis.

$\checkmark$ From this tests, Self-healing concrete is environmental friendly, heals early age cracks, high quality structures are provided.

$\checkmark \quad$ A maximum compressive strength of $36 \mathrm{Mpa}$ is achieved.

$\checkmark \quad$ It can be used for water retaining structures hence the stored water will not be leaked as they heal early age cracks.

$\checkmark \quad$ They are also used in constructing underground retaining structures for hazardous wastes.

$\checkmark \quad$ It reduces Permeability of the concrete.

$\checkmark \quad$ It increases Durability of the concrete.

\subsection{ADVANTAGES}

$\checkmark$ Reduction in permeability of concrete.

$\checkmark \quad$ It increases durability of concrete.

$\checkmark \quad$ It is pollution free, eco-friendly and natural.

$\checkmark \quad$ Lower repair and maintenance cost.

$\checkmark$ Applicable to existing buildings in the form of spray.

\subsection{DISADVANTAGES}

$\checkmark \quad$ Initial cost is higher.

$\checkmark$ Non-availability of IS codes for providing bacteria.

\subsection{APPLICATIONS}

$\checkmark$ Repairing of monuments.

$\checkmark$ Healing of concrete cracks.

$\checkmark$ Used in water retaining structures.

$\checkmark$ Used in low cost durable roads.

\section{REFERENCES}

[1] Parekar, Pawar, Suyog “ Bacteria based Self-Healing Concrete" in the International Journal of Engineering and Technology - 2018

[2] Gupta Souradeep, Pang Sze Dai, Kua Harn Wei a " Autonomous healing in concrete by Bio based healing agents" in the journal of Construction and Building materials - 2017

[3] Aslam Hussain, Rishabh Lala, Salim Akhtar , "Self-healing concrete" in the International Journal of Recent Scientific Research - 2015

[4] Luo, Qian, Li " Factors affecting crack repairing capacity of bacteria based self-healing concrete" in the journal Construction and Building Material - 2014

[5] Mohamad Ali, Mohamad Zin, Rosli and Lee " Self-healing concrete research development in the Journal of Environmental Treatment Techniques - 2014

[6] De Belie, Wang, Van Tittleboom, Verstraete " Use of silica gel or poly urethane immobilized bacteria of self-healing concrete" in the journal of Construction and Building materials -2012

[7] Homma, Mihashi, Nishiwaki "Self-healing capability of fibre reinforced cementitious composites" in the Journal of Advanced Concrete Technology - 2009

[8] Hammes, Verstraete " Key Roles of $\mathrm{pH}$ and Calcium metabolism in microbial carbonate precipitation" in the journal of environmental science biotechnology - 2002 